\title{
Monoclonal anti-erythrocyte autoantibodies derived from NZB mice cause autoimmune hemolytic anemia by two distinct pathogenic mechanisms
}

\author{
Takanori Shibata, Thierry Berney, Luc Reininger, Yves Chicheportiche, \\ Shoichi Ozaki ${ }^{1,2}$, Toshikazu Shirai ${ }^{1}$, and Shozo Izui \\ Department of Pathology, Centre Médical Universitaire, University of Geneva, Geneva, Switzerland \\ 1 Department of Pathology, Juntendo University School of Medicine, Tokyo, Japan \\ 2Present address: Laboratory of Immunology, Department of Clinical Research, Utano National Hospital, \\ Kyoto 616, Japan
}

Key words: Coombs autoantibodies, Fc receptor, erythrophagocytosis

\begin{abstract}
In vivo pathological manifestations of eight monoclonal anti-mouse red blood cell (MRBC) autoantibodies obtained from unmanipulated NZB mice were determined in BALB/C mice. Three (two IgG1 and one IgG2a) of four IgG monoclonal antibodies (mAb) and two of four IgM mAb were able to induce anemia following their i.p. injection. All five pathogenic anti-MRBC mAbs reacted only with MRBC, whereas non-pathogenic anti-MRBC $\mathrm{mAbs}$ showed binding to different species of RBC. Competition studies suggested the presence of at least two distinct epitopes recognized by our pathogenic anti-MRBC mAb. Histological examinations revealed that anemia resulted from either marked sequestration of agglutinated MRBC in spleens and livers or erythrophagocytosis, most remarkably by Kupffer cells in livers. This difference was correlated with the ability of each mAb to mediate Fc receptor-dependent phagocytosis by macrophages. The absence of complement-mediated hemolysis in vitro and the development of anemia in C5-deficient or C3-depleted mice indicated a minor role, if any, for complement-mediated lysis in the anemia induced by our anti-MRBC mAb. Our results suggest that (i) at least two different pathogenic epitopes are implicated in autoimmune hemolytic anemia; and (ii) sequestration of agglutinated MRBC in spleens and livers and Fc receptor-dependent phagocytosis, but not complement-mediated hemolysis, are the major mechanisms for the development of autoimmune hemolytic anemia.
\end{abstract}

\section{Introduction}

NZB mice spontaneously develop autoimmune hemolytic anemia as a result of production of Coombs antibodies reacting with their own red blood cells (1). Although the molecular nature of these autoantigens responsible for the induction of autoimmune responses has not been well characterized, it has been shown that there exist two major groups of anti-mouse red blood cells (MRBC) autoantibodies: one is predominantly of the $\operatorname{lgG}$ class and reacts with an exposed surface determinant of intact MRBC, referred to as antigen ' $X$ ', and the other predominantly of the Ig $M$ class reacting with an antigenic determinant, designated $\mathrm{HB}$, that is exposed only after treatment of MRBC with proteolytic enzymes such as bromelin $(2,3)$. Clearly, anti-MRBC auto- antibodies specific for ' $X$ ' antigen are of primary significance in the development of autoimmune hemolytic anemia of NZB mice. In addition to their specificities, the Ig heavy chain class of anti-MRBC autoantibodies apparently plays a significant role in the pathogenesis of anemia by determining different effector functions, such as complement-dependent hemolysis, Fc receptor-mediated phagocytosis, and multivalency-induced hemagglutination (4).

Development of several monoclonal antibodies $(\mathrm{mAb})$ reacting with intact $M R B C$, derived from unimmunized or rat RBCimmunized NZB mice, has been reported previously $(5-8)$. Intraperitoneal implantation of hybridoma cells secreting $\operatorname{lgM}$

Correspondence to: S. Izui, Department of Pathology, CMU, 1 rue Michel-Servet, 1211 Geneva 4, Switzerland 
anti-MRBC $\mathrm{mAb}$ could induce anemia, as documented by a decrease in hematocrits $(\mathrm{Ht})(6-8)$. However, some hybridoma cells secreting anti-MRBC mAb failed to induce significant anemia (6), and the implantation of non-anti-RBC hybridoma cells could cause anemia as a result of i.p. hemorrhage due to their vascular invasion. Therefore, the interpretation for the development of anemia following the i.p. injection of hybridoma cells should be cautious. In the present study we have assessed the in vivo pathogenic activity of eight anti-MRBC mAb, obtained from unmanipulated anemic NZB mice, by a single i.p. injection of purified $m A b$ and determined their pathogenic mechanisms in relation to the specificities and effector functions of anti-MRBC $\mathrm{mAb}$. Our results indicate that five of eight mAb were able to cause anemia within a few days due to either Fc receptormediated erythrophagocytosis or marked sequestration of agglutinatated MRBC in spleens and livers, and that at least two distinct species-specific antigens of MRBC were involved in the pathogenesis of autoimmune hemolytic anemia.

\section{Methods}

\section{Mice}

$\mathrm{NZB}, \mathrm{BALB} / \mathrm{c}$, and DBA/2 mice were purchased from $\mathrm{Gl}$. Bomholtgart Ltd, Ry, Denmark. Mice were bled from the retroorbital plexus and the resulting sera were stored at $-20^{\circ} \mathrm{C}$.

\section{Anti-MRBC and other $M A b$}

Hybridomas used in this study were derived from four different fusions of spleen cells from unmanipulated adult anemic NZB mice with the myeloma cell lines, NS-2 or X63-Ag8.653. Anti-MRBC autoantibody activities in hybridoma supernatants were detected by an indirect radioimmunoassay (RIA) as described below. Positive hybridomas were cloned by limiting dilution. Hybridoma cells were maintained in Dulbecco's modified Eagle's medium (DMEM) supplemented with additional amino acids (9), $10 \mathrm{mM}$ HEPES, $5 \times 10^{-5} \mathrm{M}$ 2-mercaptoethanol, and $10 \%$ FCS. Isotypes of anti-MRBC mAb and their concentrations were determined by lg class-specific enzyme-linked immunosorbent assays (ELISA) as described previously (10). IgM anti-bromelinized MRBC (CP3.23-24) mAb (11), IgM (41-5C) $m A b$ derived from NZB mice, and $\operatorname{lgG} 1, \lg G 2 a$, and $\operatorname{lgG} 2 b$ anti-dinitrophenyl $\mathrm{mAb}$ (12) were used as controls. Rat anti-mouse IgG Fc receptor $\mathrm{mAb}(2.4 \mathrm{G} 2)$ was kindly provided by $\mathrm{Dr} \mathrm{J}$. C. Unkeless, Mount Sinai School of Medicine, New York (13).

\section{Purification, concentration, and iodination of antibodies}

IgG mAb were purified from culture supernatants using a staphylococcal protein A column (Pharmacia Fine Chemicals, Uppsala, Sweden). IgM mAb were purified by euglobulin precipitation from either ascites or culture supernatants concentrated by $50 \%$ saturated ammonium sulphate precipitation, according to the method of Garcia-Gonzales et al. (14). The purity of IgG and $\operatorname{lgM}$ mAb was $>90 \%$ as documented by SDS - PAGE. For some in vivo experiments, culture supernatants were concentrated $\times 10$ by $50 \%$ saturated ammonium sulphate precipitation. Polyclonal mouse IgG was prepared from pooled normal mouse serum on a protein $A$ affinity column. Purified polyclonal and $\mathrm{mAb}$ were labeled with ${ }^{125}$ by the chloramin $\mathrm{T}$ method (15)
Indirect anti-MRBC assay

An indirect RIA was used to detect anti-MRBC activities in culture supernatants or sera. One hundred microliters of hybridoma culture supernatants or 1:1000 diluted sera were incubated with $10 \mu \mathrm{l}$ of $25 \% \mathrm{MRBC}$ suspension freshly prepared from $\mathrm{BALB} / \mathrm{C}$ mice overnight at $4^{\circ} \mathrm{C}$, room temperature, or $37^{\circ} \mathrm{C}$. After washing three times with PBS, the MRBC were incubated overnight at $4^{\circ} \mathrm{C}$ with $100 \mu \mathrm{l}$ of 125 -labeled rabbit anti-mouse Ig (DAKOPATTS, Copenhagen, Denmark) or $125 \mathrm{l}$-labeled rat anti-mouse $\mu$ chain-specific mAb (LO-MM-9; a kind gift of $\mathrm{Dr} \mathrm{H}$. Bazin, Belgium) (16) in 1\% BSA - PBS. After washing with PBS, the radioactivity bound to MRBC was counted in a $\gamma$-counter. Results are expressed as the percentage of [125|]anti-mouse Ig bound to MRBC. This indirect RIA was also used for the determination of anti-MRBC mAb binding to different species (human, sheep, chick, rabbit, and rat) of RBC. Sheep RBC and chick RBC were purchased from Behringwerke AG, Marburg, FRG, and Flow Laboratories, Allschwil, Switzerland, respectively.

\section{Competitive inhibition assay}

Fifty nanograms of 125 -labeled anti-MRBC mAb diluted in $50 \mu \mathrm{l}$ of $1 \%$ BSA - PBS were mixed with $50 \mu \mathrm{l}$ of various amounts of different unlabeled $\mathrm{mAb}$, followed by the addition of $50 \mu \mathrm{l}$ of $0.2 \%$ MRBC suspension. After an overnight incubation at $4^{\circ} \mathrm{C}$, the mixtures were washed three times with PBS and the radioactivity bound to MRBC was counted. Results are expressed as the percentage inhibition of [125] ]anti-MRBC $m A b$ binding to MRBC.

\section{Direct anti-MRBC assay}

In vivo bound anti-MRBC $\mathrm{mAb}$ were detected by a direct anti-MRBC RIA. Fifty microliters of blood samples were collected into heparinized tubes containing $1 \mathrm{ml}$ of PBS. After washing four times, $50 \mu \mathrm{l}$ of $2.5 \%$ MRBC suspension in $1 \%$ BSA - PBS were incubated with $50 \mu$ l of either [125]]rabbit anti-mouse Ig or [125I]rat anti-mouse $\mu$ chain-specific mAb (LO-MM-9) at $4^{\circ} \mathrm{C}$. After washing three times, the radioactivity bound to MRBC was counted by a $\gamma$-counter. Results are expressed as the percentage of [125|]anti-mouse Ig bound to MRBC

\section{Determination of $\mathrm{Ht}$}

Blood samples were collected into heparinized microhematocrit tubes (Clay Adams, Parsippany, NY) and centrifuged at 12,000 r.p.m. for $5 \mathrm{~min}$ in a microfuge (Sigma-201 M, Auer Bittmann Soulié AG, Geneva, Switzerland). Percentage of packed RBC volume was directly measured after centrifugation.

\section{Histopathology}

Major organs including spleens and livers were obtained at autopsy, processed for histological examination, and stained with hematoxylin and eosin (HE).

\section{In vivo depletion of $\mathrm{C3}$}

To deplete $\mathrm{C} 3, \mathrm{BALB} / \mathrm{c}$ mice received three i.v. injections of Naja naja cobra venom factor (CVF, Diamedix Corp., Miami, FL): $7.5 \mathrm{U}$ CVF $8 \mathrm{~h}$ before the injection of anti-MRBC MAb and $2.5 \mathrm{U}$ CVF 1 and 2 days after the anti-MRBC mAb injection. This treatment decreased serum levels of $\mathrm{C} 3$ to $-5 \%$ of control values, as determined by radial immunodiffusion. 


\section{Complement-mediated lysis}

Fifty microliters of $0.25,0.5$, or $1 \%$ MRBC suspension were incubated with $100 \mu$ l of various concentrations $(0.1-100 \mu \mathrm{g} / \mathrm{ml})$ of anti-MRBC or control mAb at room temperature for $60 \mathrm{~min}$ in round-bottom microtiter plates (Sterilin Ltd, Feltham, UK). After washing with Hanks' medium, $50 \mu \mathrm{l}$ of $10 \%$ guinea pig, rabbit (Cedarlane Laboratories, Ltd, Ontario, Canada), or fresh mouse serum were added as a source of complement. The suspensions were incubated at $37^{\circ} \mathrm{C}$ for $30 \mathrm{~min}$, then hemolysis was determined macroscopically.

\section{Opsonization of MRBC with anti-MRBC $m A b$}

Five hundred microliters of packed MRBC freshly prepared from BALB/c mice were incubated with $50 \mu \mathrm{g}$ of purified $\mathrm{mAb}$ in $10 \mathrm{ml}$ of $1 \%$ BSA - PBS. After incubation for $30 \mathrm{~min}$ at room temperature, and washing with PBS, a $50 \%$ suspension of opsonized MRBC in PBS was prepared.

\section{In vitro $F_{C}$ receptor-mediated phagocytosis}

Peritoneal cells were collected from unmanipulated BALB/c mice and suspended in DMEM. Peritoneal cells $\left(3 \times 10^{5}\right)$ were then allowed to adhere to Falcon 6-well plates by $1 \mathrm{~h}$ incubation at $37^{\circ} \mathrm{C}$. Following washing, adherent cells, which consisted of -99\% macrophages as revealed by Giemsa staining, were further incubated at $37^{\circ} \mathrm{C}$ overnight in a humidified incubator containing $5 \% \mathrm{CO}_{2}$ in air. One hundred microliters of $50 \%$ opsonized MRBC suspension were added to adherent macrophages and incubated at $37^{\circ} \mathrm{C}$ for $1 \mathrm{~h}$. After extensive washings with Hanks' medium, plates were treated with distilled water for $10 \mathrm{~s}$ to lyse extracellular MRBC. Isotonicity was quickly restored by adding Hanks' medium.

\section{Hemagglutination assay}

A one-step hemagglutination assay was performed as follows. Fifty microliters of serial dilutions of culture supernatants were mixed with $50 \mu \mathrm{l}$ of $0.5 \%$ MRBC suspension in $1 \%$ BSA - PBS in round-bottom microtiter plates and incubated at room temperature for $1 \mathrm{~h}$. In each experiment, control $\mathrm{IgG}$ and $\operatorname{lgM} \mathrm{mAb}$ or $1 \% \mathrm{BSA}$ - PBS were used as negative controls. Hemagglutination titers are expressed as the reciprocal of the final dilution, giving a positive macroscopic hemagglutination.

\section{Results}

In vitro binding activity of anti-MRBC $m A b$ to $R B C$

Eight hybridomas secreting $\operatorname{IgM}(1 \mathrm{E} 10,4 \mathrm{C} 8,103-7 \mathrm{E}$, and 106-10E), IgG1 (31-9D and 105-2H), IgG2b (34-2B), or IgG2a (34-3C) anti-MRBC mAb were prepared from four separate fusions with spleen cells of anemic NZB mice. All eight $m A b$ exhibited significantly increased binding activities to intact MRBC at $4^{\circ} \mathrm{C}$ compared with control $\mathrm{mAb}$ and polyclonal mouse IgG (Table 1). Essentially identical activities were observed at room temperature and at $37^{\circ} \mathrm{C}$ except for the $4 \mathrm{C} 8$ and $103-7 \mathrm{E} \mathrm{mAb}$, which showed slightly higher binding activity at $4^{\circ} \mathrm{C}(35.2$ and $23.6 \%)$ than at room temperature $(21.6$ and $13.4 \%)$ or $37^{\circ} \mathrm{C}(21.2$ and $12.4 \%$ ).

When the binding of these anti-MRBC mAb with RBC from five different species (rat, sheep, rabbit, chick, and human) was examined, three different groups of anti-MRBC mAb were
Table 1. In vitro binding of anti-MRBC $m A b$ to different species of $\mathrm{RBC}$

\begin{tabular}{|c|c|c|c|c|c|c|}
\hline$m A b^{a}$ & Mouse & Rat & Sheep & Rabbit & Chick & Human \\
\hline $1 \mathrm{E} 10(\mu, x)$ & 40.7 & 0.3 & 0.9 & 0.7 & 0.5 & 0.2 \\
\hline $4 C 8(\mu, x)$ & 45.5 & 1.7 & 2.6 & 0.8 & 0.7 & 0.8 \\
\hline $31-9 D(\gamma 1, x)$ & 18.4 & 0.6 & 1.0 & 0.8 & 0.6 & 0.3 \\
\hline $105-2 \mathrm{H}(\gamma 1, x)$ & 20.2 & 0.7 & 1.9 & 1.3 & 0.7 & 0.9 \\
\hline $34-3 C(\gamma 2 a, x)$ & 21.0 & 0.5 & 1.0 & 1.7 & 1.0 & 0.4 \\
\hline $34-2 \mathrm{~B}(\gamma 2 \mathrm{~b}, \kappa)$ & 13.6 & 8.4 & 1.2 & 1.0 & 0.8 & 1.2 \\
\hline 103-7E $(\mu, x)$ & 57.9 & 59.0 & 64.2 & 49.8 & 71.3 & 22.5 \\
\hline $106-10 \mathrm{E}(\mu, x)$ & 44.1 & 39.3 & 22.0 & 25.6 & 38.7 & 32.4 \\
\hline
\end{tabular}

a2 $\mu \mathrm{g}$ of each $\mathrm{mAb}$ were incubated with RBC from different species overnight at $4^{\circ} \mathrm{C}$. Results are expressed as percentage of 125 -labeled anti-mouse lg bound to RBC. Background binding activities obtained by control $\lg M$ and $\lg G \mathrm{mAb}$ or by polyclonal mouse $\lg \mathrm{G}$ from a pooled normal mouse serum were $<2 \%$.

identified (Table 1). The first group, consisting of $1 \mathrm{E} 10,4 \mathrm{C} 8$, 31-9D, 105-2H, and 34-3C mAb, reacted with only MRBC. The second group (34-2B mAb) exhibited binding activity with both mouse and rat RBC. The third group (103-7E and 106-10E) reacted with the RBC of all species tested.

To further define the specificity of the first group of anti-MRBC $\mathrm{mAb}, 34-3 \mathrm{C}, 1 \mathrm{E} 10$, or $4 \mathrm{C} 8 \mathrm{mAb}$ was iodinated and the competitive inhibition assay was performed in the presence of excess amounts of different $\mathrm{mAb}$. As shown in Fig. 1, not only the 34-3C mAb but also the 105-2 $\mathrm{H}$ mAb were able to inhibit almost completely the MRBC-binding by the [125|]34-3C mAb. However, the inhibitory activity of $34-3 \mathrm{C}$ mAb was $\sim 25$-fold stronger than that of $105-2 \mathrm{H}$ mAb. A slight inhibition (15\%) by 200-fold excess of $1 \mathrm{E} 10$ or $4 \mathrm{C} 8 \mathrm{mAb}$ was observed, and no inhibition by other anti-MRBC $\mathrm{mAb}$ (31-9D, 34-2B, 103-7E, and 106-10E). When the competition assay was performed with [125I]1E10 mAb, 34-3C mAb exhibited the highest inhibitory activity (Fig. 1). In fact, 80 ng of 34-3C mAb completely inhibited the binding of $50 \mathrm{ng}$ of [125]] $1 \mathrm{E} 10 \mathrm{mAb}$, while only $50 \%$ inhibition was achieved by the same amount of $1 \mathrm{E} 10 \mathrm{mAb}$. The $4 \mathrm{C} 8$ and $105-2 \mathrm{H} \mathrm{mAb}$ exhibited similar inhibitory activity to that of the $1 \mathrm{E} 10 \mathrm{mAb}$ : all three $\mathrm{mAb}$ at a dose of $2 \mu \mathrm{g}$ completely inhibited the MRBC-binding of [125|]1E10 mAb. Partial inhibition was observed by 103-7E and 31-9D mAb at 40- to 200-fold excess, and no inhibition by $34-2 \mathrm{~B}$ and $106-10 \mathrm{E}$ mAb. When [125] $4 \mathrm{C} 8$ $\mathrm{mAb}$ was used for the competition assay, results were essentially identical to those obtained with [125|]1E10 mAb (data not shown). These results suggested that $1 \mathrm{E} 10,4 \mathrm{C} 8,105-2 \mathrm{H}$, and 34-3C mAb may recognize the same antigen-different from that recognized by the 31-90 mAb-and, if so, the affinity of the 34-3C $\mathrm{mAb}$ is far higher than that of the others.

\section{Induction of anemia by the injection of anti-MRBC $M A b$}

Since eight anti-MRBC mAb exhibited substantial binding activity to intact $\mathrm{MRBC}$ in vitro at $37^{\circ} \mathrm{C}$ as well as at $4^{\circ} \mathrm{C}$, the pathogenicity of anti-MRBC $\mathrm{mAb}$ was investigated by a single i.p. injection of purified $\mathrm{mAb}$ in BALB/c mice. The injection of $100 \mu \mathrm{g}$ of purified $\mathrm{mAb}$ of two $\operatorname{lgM}(1 \mathrm{E} 10$ and $4 \mathrm{C} 8$ ), IgG1 31-9D, or lgG2a 34-3C mAb caused a rapid decrease in $\mathrm{Ht}$ values, and $1 \mathrm{E} 10 \mathrm{mAb}$ even killed all animals within 1 or 2 days after its injection (Fig. 2). In contrast, IgG1 105-2H, IgG2b 34-2B, and 


\section{5|-34-3C mAb}

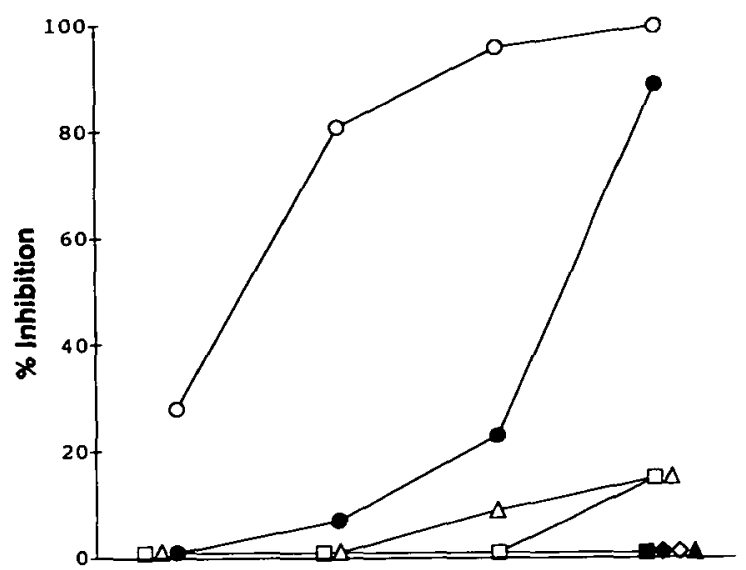

125|-1E10 MAb

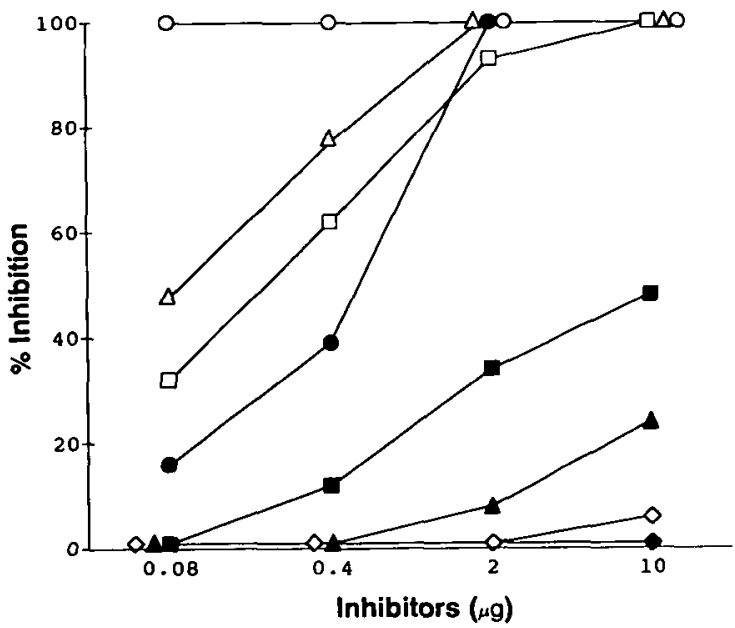

Fig. 1. Inhibitory activities of various amounts of unlabeled anti-MRBC $\mathrm{mAb}\left(\mathrm{O}, 34-3 \mathrm{C} ; \bullet, 105-2 \mathrm{H} ; \triangle, 1 \mathrm{E} 10 ; \Delta, 31-9 \mathrm{D} ; \square, 4 C 8 ; \mathbf{\square}, 103-7 \mathrm{E}_{\text {; }}\right.$ $\diamond, 34-2 \mathrm{~B} ;, 106-10 \mathrm{E}$ ) on the MRBC-binding by $50 \mathrm{ng}$ of [1251]34-3C or [ $\left.{ }^{125}\right]$ ]E10 anti-MRBC MAb. Results are expressed as percentage inhibition of $\left[{ }^{125}\right]\left[34-3 \mathrm{C}\right.$ or $\left.\left[{ }^{125}\right]\right] 1 \mathrm{E} 10 \mathrm{mAb}$-binding to MRBC.

two lgM (103-7E and 106-10E) mAb were not able to significantly decrease $\mathrm{Ht}$ values.

To compare the pathogenic activity of the anti-MRBC mAb quantitatively, various amounts of $\mathrm{mAb}$ were injected and the quantities of $\mathrm{mAb}$ required to induce anemia (decreasing $\mathrm{Ht}$ values to $<40 \%$ ), to cause a $50 \%$ decrease in $\mathrm{Ht}$ values (decreasing $\mathrm{Ht}$ values to $<24 \%$ ), and to kill animals were estimated. The 31-9D mAb exhibited the strongest activity for inducing anemia (Table 2). In fact, only $5 \mu \mathrm{g}$ of $\mathrm{mAb}$ were sufficient to induce anemia; $\mathrm{Ht}$ values dropped from 50 to $34 \%$ 4 days after the injection. This dose was 5-10 times less than that of the other three highly pathogenic $\mathrm{mAb}$ (34-3C, $1 \mathrm{E} 10$, and $4 \mathrm{C} 8$ ). Similar differences were observed when compared with the amount of $\mathrm{mAb}$ required for a $50 \%$ decrease in $\mathrm{Ht}$ values. However, the $1 \mathrm{E} 10 \mathrm{mAb}$ was most toxic, because only $100 \mu \mathrm{g}$ were sufficient to kill mice, while 2.5-5 times more mAb was required for $31-9 \mathrm{D}, 4 \mathrm{C} 8$, and $34-3 \mathrm{C} \mathrm{mAb}$. Although $100 \mu \mathrm{g}$ of $105-2 \mathrm{H}$ mAb failed to induce anemia, anemia was observed at
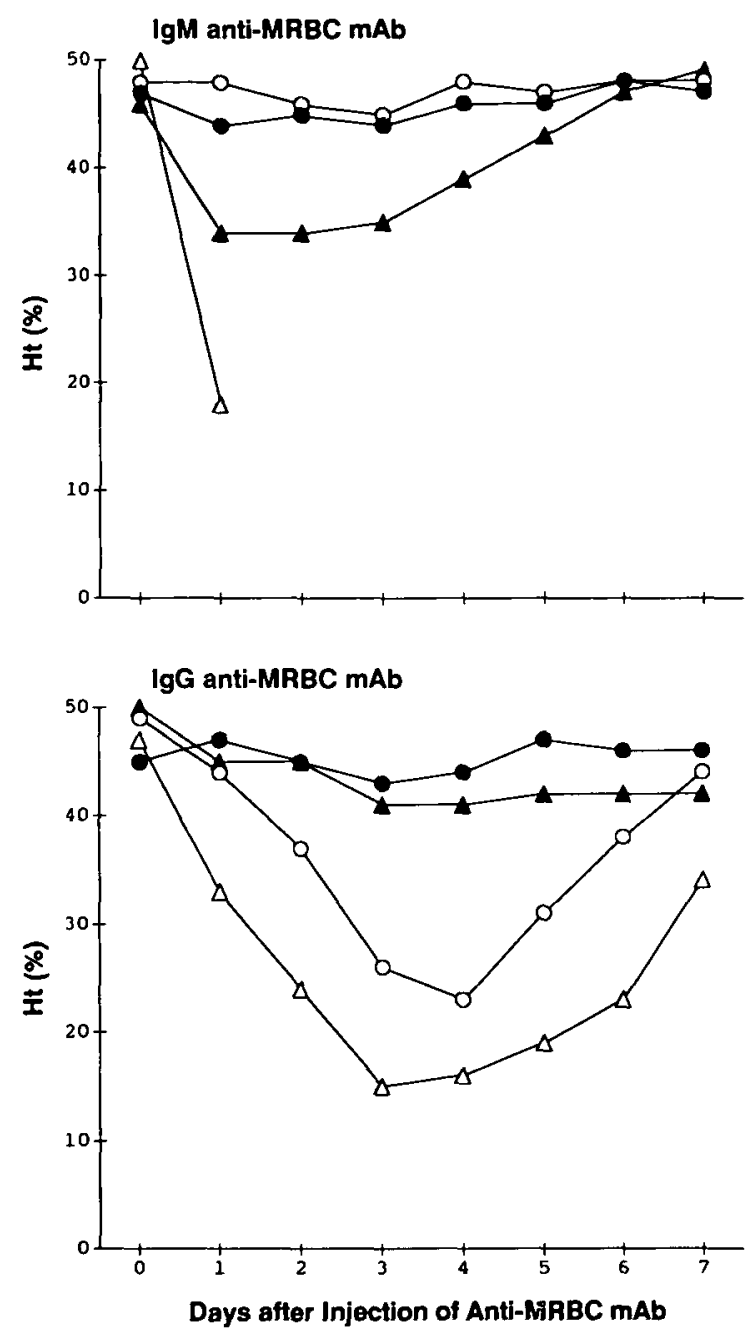

Fig. 2. Development of anemia in $B A L B / C$ mice after a single i.p. injection of $100 \mu \mathrm{g}$ of purified IgM anti-MRBC mAb (upper panel: $\triangle, 1 \mathrm{E} 10$ A, 4C8; O, 103-7E; - 106-10E) or IgG anti-MRBC mAb (lower panel: $\triangle, 31-9 \mathrm{D} ; \boldsymbol{\Delta}, 105-2 \mathrm{H} ; \mathrm{O}, 34-3 \mathrm{C} ; \bullet, 34-2 \mathrm{~B})$. Results are mean Hit values of five mice. Note that all the mice injected with $1 E 10 \mathrm{mAb}$ died within 2 days after injection.

Table 2. Estimation of quantities of $m A b$ required for inducing anemia and killing mice

\begin{tabular}{lccc}
\hline mAb & $\begin{array}{l}\text { Dose required for } \\
\text { inducing anemia } \\
(\mu \mathrm{g})\end{array}$ & $\begin{array}{l}\text { Dose required for } \\
50 \% \text { decrease in } \mathrm{H}^{\mathrm{b}} \\
(\mu \mathrm{g})\end{array}$ & $\begin{array}{l}\text { Lethal dose } \\
(\mu \mathrm{g})\end{array}$ \\
\hline $1 \mathrm{E} 10$ & 25 & 75 & 100 \\
$4 \mathrm{C8}$ & 50 & 200 & 250 \\
$31-9 \mathrm{D}$ & 5 & 15 & 250 \\
$105-2 \mathrm{H}$ & 250 & 1200 & $\mathrm{ND}$ \\
$34-2 \mathrm{C}$ & 50 & 100 & 500 \\
\hline
\end{tabular}

aThe quantity of mAb required for inducing anemia. $\mathrm{Ht}$ values $<40 \%$ $(=<3 \mathrm{SD}$ irom mean values of 3 - to 4 -month-old BALB/c mice) were considered as anemic

bThe quantity of mAb required for causing a $50 \%$ decrease in $\mathrm{Ht}$ values $(\mathrm{Ht}$ values decreased to $<24 \%$ ).

cNot determined. 
Table 3. In vivo MRBC binding by pathogenic but not non-pathogenic anti-MRBC mAb

\begin{tabular}{lcrc}
\hline $\mathrm{mAb}$ & $\mathrm{Ht}(\%)$ & mAb bound to MRBCa & Free anti-MRBCb \\
\hline $1 \mathrm{E} 10$ & $17 \pm 2$ & $17.2 \pm 3.3$ & 1.2 \\
$4 \mathrm{C} 8$ & $20 \pm 8$ & $23.4 \pm 5.9$ & 0.5 \\
$31-9 \mathrm{D}$ & $16 \pm 3$ & $9.6 \pm 0.9$ & 1.1 \\
$105-2 \mathrm{H}$ & $20 \pm 2$ & $10.3 \pm 0.8$ & 1.0 \\
$34-3 \mathrm{C}$ & $21 \pm 5$ & $9.4 \pm 0.8$ & 1.3 \\
$103-7 \mathrm{E}$ & $46 \pm 3$ & $0.7 \pm 0.2$ & 22.2 \\
$106-10 \mathrm{E}$ & $44 \pm 2$ & $0.6 \pm 0.3$ & 27.5 \\
$34-2 \mathrm{~B}$ & $43 \pm 2$ & $1.9 \pm 0.2$ & 8.0 \\
\hline
\end{tabular}

a5-10 days after injection of $5 \times 10^{6}$ hybridoma cells, the amount of $\mathrm{mAb}$ bound to MRBC in vivo was determined by direct RIA. Results are expressed as percentage binding of [125|]anti-mouse lg on MRBC (mean of 4-8 mice $\pm 1 \mathrm{SD}$ ). Background binding activities obtained in mice injected with control hybridomas were $<2 \%$.

bFree anti-MRBC activities in 1/1000 diluted sera pooled from $4-8$ mice were determined by indirect RIA. Results are expressed as percentage binding of [ $\left.{ }^{125} \mid\right]$ anti-mouse Ig bound to MRBC. Background binding activities in sera from mice injected with control hybridomas were $<1 \%$.

a dose of $250 \mu \mathrm{g}$, which was 50 times higher than that of 31-9D $\mathrm{mAb}$ of the same lg subclass, and $1.2 \mathrm{mg}$ was required to cause a $50 \%$ decrease in $\mathrm{Ht}$ values. Notably, no anemia developed following the injection of ascites containing $10 \mathrm{mg}$ of $\operatorname{lgG} 2 \mathrm{~b}$ 34-2B, IgM (103-7E and 106-10E) anti-MRBC mAb, or control $m A b$ of any IgG subclass or IgM, including anti-bromelinized MRBC mAb.

Lack of in vivo $M R B C$ binding by non-pathogenic anti-MRBC $m A b$

Since experiments of anti-MRBC mAb injection have shown that three of eight anti-MRBC $m A b$ failed to induce anemia, we examined whether these mAb were able to bind MRBC in vivo. In mice developing anemia 5 - 10 days after the injection of five different hybridoma cells, significant amounts of antibodies bound to MRBC were detectable in all cases, while there was no demonstrable activity of free anti-MRBC antibodies in their sera (Table 3). In contrast, none of the mice transplanted with three non-pathogenic anti-MRBC hybridomas had MRBC bound with anti-MRBC antibodies at a significant level, although substantial activity of unbound anti-MRBC antibodies was found in their sera.

Histopathological manifestations induced by the injection of anti-MRBC $M A b$

Histological examinations revealed two different pathological changes, depending on the mAb, in spleens and livers of the mice which had either died of acute anemia or developed a severe anemia after the injection of $m A b$. The first group of $m A b$, i.e. two $\lg M(1 E 10$ and $4 C 8)$ and $\lg G 1$ (31-90) $M A b$ at a dose of $100-250 \mu \mathrm{g}$, induced a marked splenomegaly associated with an enormous accumulation of agglutinated RBC in the spleen, which prevented recognition of splenic architecture (Fig. 3A). In the liver agglutinated RBC were accumulated in sinusoids, causing marked necrosis of hepatic parenchymal cells (Fig. 3B). However, erythrophagocytosis by Kupffer cells or by splenic macrophages was barely detectable. In contrast, in mice administered by the second group of $\mathrm{mAb}, 500 \mu \mathrm{g}$ of $\operatorname{lgG} 2 \mathrm{a}$
(34-3C) or 2 mg of lgG1 (105-2H), erythrophagocytosis by Kupffer cells was the most remarkable pathological change (Fig. $3 \mathrm{C}$ and D). Notably, no significant histological alterations were observed in mice injected with ascites containing $10 \mathrm{mg}$ of three other anti-MRBC mAb (34-2B, 103-7E, and 106-10E) or control mAb (Fig. $3 E$ and $F$ ).

Induction of anemia in C5-deficient or C3-depleted mice by anti-MRBC $\mathrm{MAb}$

To determine the role of complement-mediated lysis in anemia induced by MRBC mAb, $100 \mu \mathrm{g}$ of $4 \mathrm{C} 8(\mathrm{lgM}), 31-9 \mathrm{D}(\operatorname{lgG} 1)$, or 34-3C (lgG2a) were injected i.p. into C5-deficient DBA/2 mice (17), and CVF-treated or control BALB/C mice. The extent and kinetics of anemia induced by these $\mathrm{mAb}$ in DBA/2 mice were essentially identical to those in BALB/C mice (Table 4). CVFtreated BALB/C mice similarly developed anemia, although their anemia was more severe than that of the control group of mice. This was probably caused by the effect of CVF alone, since CVF-treated mice receiving control non-anti-MRBC mAb exhibited a slight decrease in $\mathrm{Ht}$ values. It should be noted that, when MRBC opsonized with these mAb were subjected to complementmediated lysis in vitro in the presence of guinea pig, rabbit, or mouse serum, no macroscopically visible hemolysis was observed (data not shown).

$F_{C}$ receptor-mediated phagocytosis and hemagglutination of $M R B C$ opsonized with anti-MRBC mAb

Because none of the mAb capable of inducing anemia caused complement-mediated hemolysis in vitro, and because both C5-deficient and C3-depleted mice developed anemia, the observed difference in pathological manifestations may be related to a difference in the ability of the anti-MRBC mAb to bind the $\mathrm{F}_{\mathrm{C} \gamma}$ receptors of macrophages and/or to induce hemagglutination. As shown in Fig. 4, MRBC opsonized with 31-9D, $4 \mathrm{C} 8$, or $1 \mathrm{E} 10 \mathrm{mAb}$ were not significantly phagocytosed by peritoneal macrophages. In contrast, remarkably high and moderate levels of phagocytosis were observed when MRBC were opsonized with IgG2a 34-3C and IgG1 105-2H mAb, respectively. Notably, this phagocytosis was completely inhibited in the presence of a rat anti-murine $\mathrm{Fc} \gamma$ receptor mAb (2.4G2) (data not shown). Finally, it was found that an i.v. administration of $1 \mathrm{mg}$ of $2.4 \mathrm{G} 2 \mathrm{mAb} 2 \mathrm{~h}$ before the anti-MRBC mAb injection completely inhibited the development of anemia induced by IgG2a 34-3C mAb, but did not inhibit at all that induced by IgG1 31-9D or IgM 4C8 mAb (Table 5).

When the hemagglutination activity was determined in vitro, both $1 \mathrm{E} 10$ and $4 \mathrm{C} 8 \mathrm{IgM}$ mAb markedly agglutinated MRBC (hemagglutination titers of culture supernatants: 1E10, 1024; 4C8, 4096). However, none of the other anti-MRBC mAb, including two non-pathogenic IgM anti-MRBC (103-7E and 106-10E) mAb, agglutinated the MRBC, although they reacted well with MRBC under this condition, as determined by RIA.

\section{Discussion}

The present study represents an extensive analysis of the pathological manifestations of eight monoclonal anti-MRBC autoantibodies obtained from unimmunized NZB mice. Although all eight anti-MRBC mAb reacted well with $M R B C$ in vitro at $37^{\circ} \mathrm{C}$ 
A

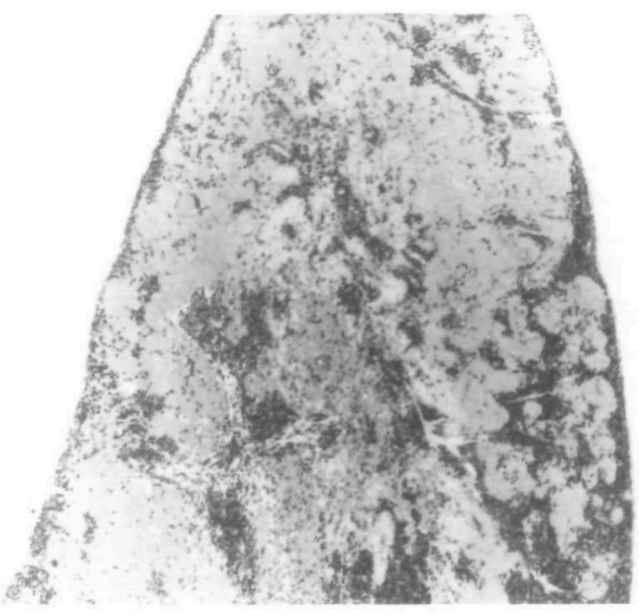

C

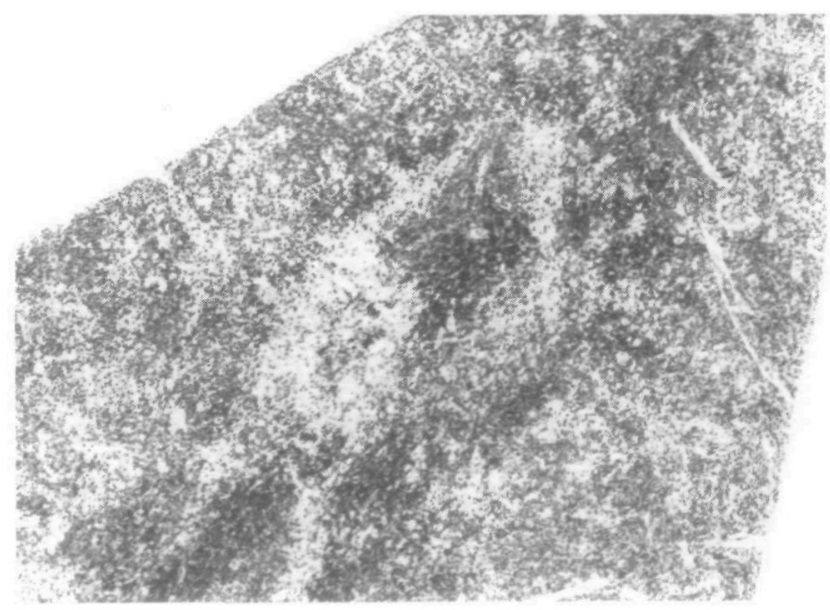

E

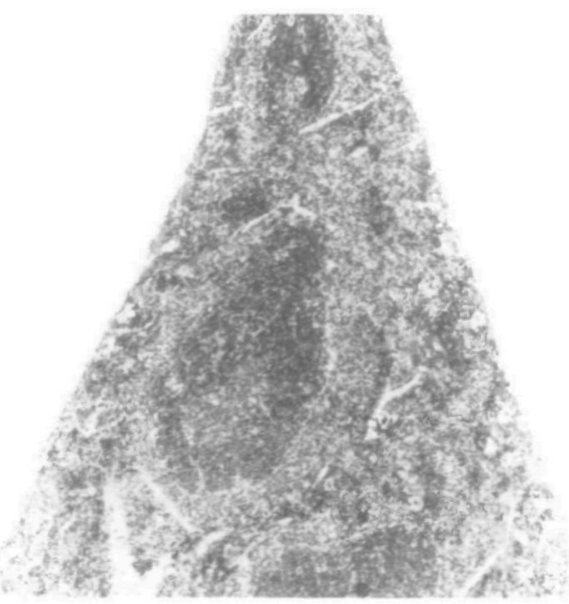

B

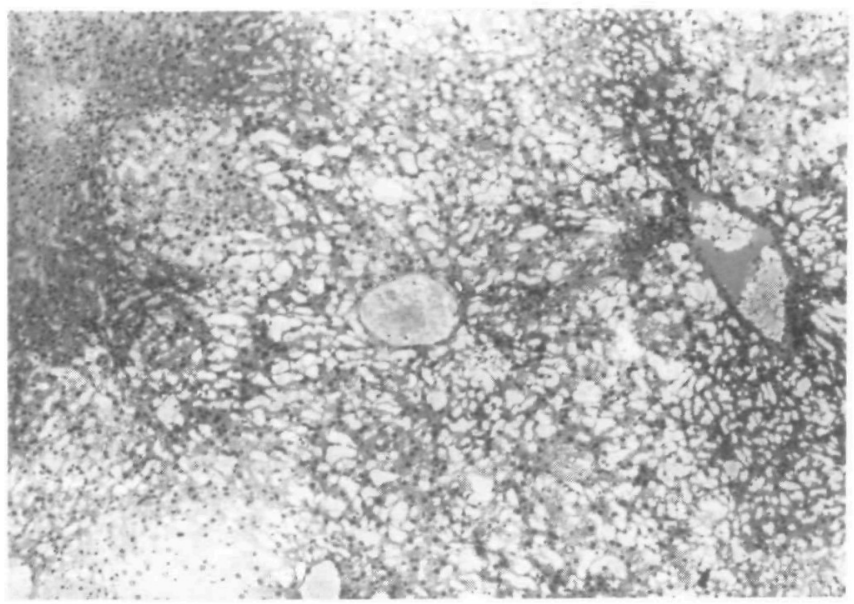

D

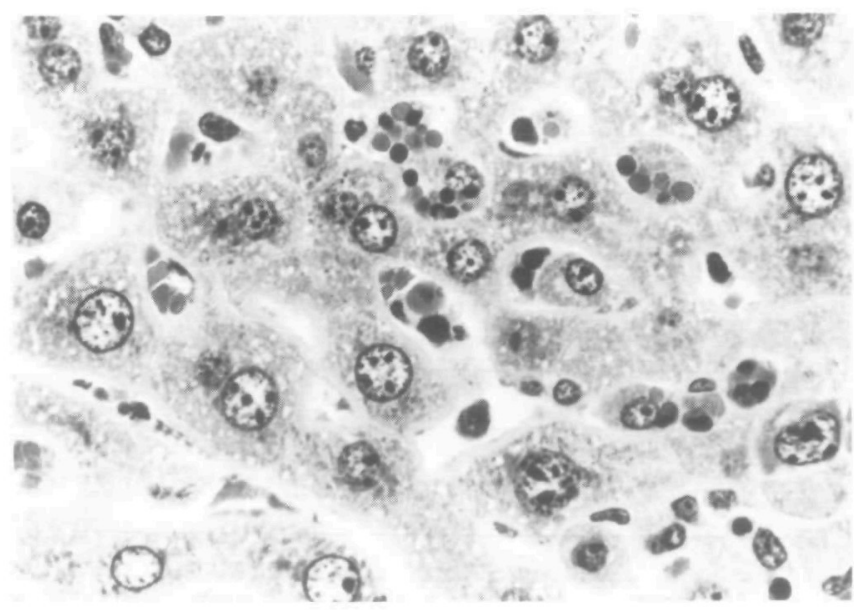

$\mathbf{F}$

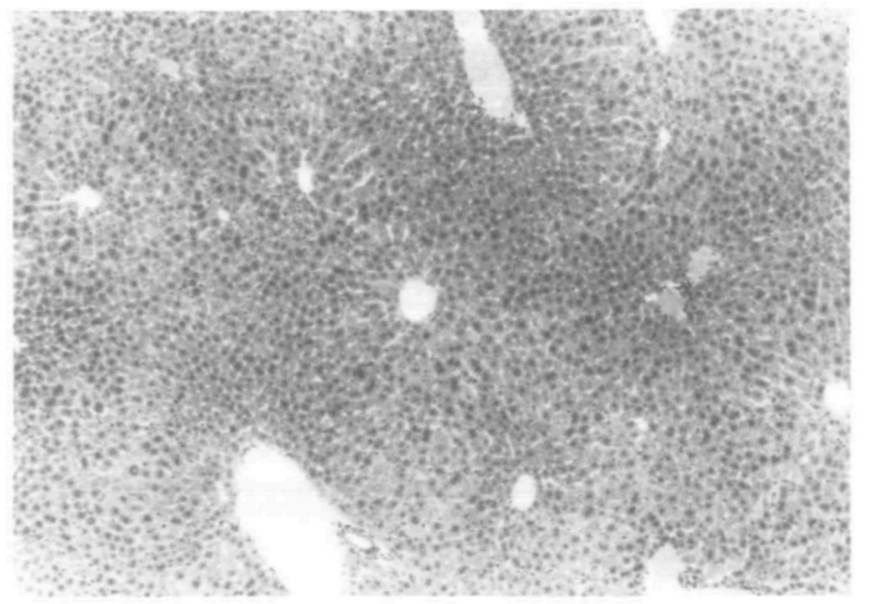

Fig. 3. ( $A$ and $B$ ) Representative histological appearance of spleen and liver trom BALB/C mice which died or anemia 2 days atter ine injecion of $100 \mu \mathrm{g}$ of $1 \mathrm{E} 10$ anti-MRBC mAb. Note an enormous accumulation of agglutinated RBC in the entire spleen, rendering the splenic architecture hardly recognizable $(A ; H E, \times 24)$, and marked necrosis of hepatic parenchymal cells secondary to the accumulation of agglutinated $R B C$ in sinusoids of liver $(\mathrm{B} ; \mathrm{HE}, \times 24)$. Essentially identical lesions were observed in mice injected with 31-9D or 4C8 mAb. (C and D) Representative histological appearance of spleen and liver from BALB/c mice which died of anemia 4 days after the injection of $500 \mu \mathrm{g}$ of $34-3 \mathrm{C}$ anti-MRBC mAb. Note the absence of accumulation of agglutinated RBC in spleen (C; HE, $\times 24)$ and liver (D; HE, $\times 240$ ) but remarkable erythrophagocytosis by Kupffer cells in liver (D). Similar histological changes were observed in mice developing anemia after the injection of $2 \mathrm{mg}$ of 105-2H mAb. (E and $F$ ) Representative histological appearance of spleen and liver in mice injected with $10 \mathrm{mg}$ of $34-2 \mathrm{~B}$ anti-MRBC mAb. Note that there are no significant histological alterations in spleen $(E ; H E, \times 24)$ and liver $(F ; H E, \times 24)$. Mice injected with either 103-7E or 106-10E mAb exhibited no appreciable changes in spleens and livers (not shown). 
as well as at $4^{\circ} \mathrm{C}$, only five of them were able to bind MRBC in vivo, causing anemia either by $\mathrm{Fc}$ receptor-mediated erythrophagocytosis or by marked sequestration of agglutinated MRBC in spleens and livers, but not by complement-mediated hemolysis. The distinct difference in the specificity between pathogenic and non-pathogenic anti-MRBC mAb strongly

Table 4. Development of anemia in C5-deficient DBA/2 and CVF-treated BALB/C mice after injection of anti-MRBC $\mathrm{mAb}$

\begin{tabular}{llll}
\hline$m A b$ & DBA/2 & BALB/c & \\
\hline $4 C 8$ & & $C V F$ & Control \\
$31-90$ & $36 \pm 3^{a}$ & $28 \pm 3^{a}$ & $35 \pm 3^{a}$ \\
$34-3 C$ & $20 \pm 1$ & $N D$ & $17 \pm 1$ \\
$41-5 C b$ & $26 \pm 2$ & $19 \pm 2$ & $24 \pm 1$ \\
\hline
\end{tabular}

aHt values (mean of 5 mice $\pm 1 \mathrm{SD}$ ) were determined 3 days after i.p. injection of $100 \mu \mathrm{g}$ of anti-MRBC mAb. CVF were injected i.v. $8 \mathrm{~h}$ before and 1 and 2 days after the anti-MRBC mAb injection. Note that serum levels of $\mathrm{C} 3$ at the time of anti-MRBC mAb injection were $\sim 5 \%$ of control values, which remained until day 3 . ND, not done.

였 non-anti-MRBC mAb suggests the importance of autoantibody specificity for the pathogenesis of autoimmune hemolytic anemia.

It is significant that all five pathogenic autoantibodies recognize only species-specific antigens (at least two distinct epitopes) on MRBC, while non-pathogenic antibodies recognize cross-reactive determinants present only on rat RBC or on RBC from many species such as human, sheep, rabbit, and chick. In this regard, it should be mentioned that one $\lg M$ anti-MRBC $\mathrm{mAb}(\mathrm{G}-8)$, established by Caulfield et al. (8) and whose pathogenic activity was demonstrated by the transplantation of hybridoma cells, also reacts specifically with MRBC. These results are consistent with earlier findings that autoantibodies eluted from RBC of Coombs-positive NZB mice react only with MRBC but not with human, rat, sheep, guinea pig, or rabbit $\operatorname{RBC}(2,18)$. Thus, at least two species-specific epitopes, as suggested by the present competition experiment, are likely to be involved in the pathogenesis of autoimmune hemolytic anemia. Clearly, the identification of the biochemical nature of pathogenic epitopes is of importance to understand the immunopathogenesis of autoimmune hemolytic anemia.

The importance of the specificity of anti-MRBC mAb in the pathogenesis of autoimmune hemolytic anemia is best documented by the finding that among four IgM anti-MRBC mAb
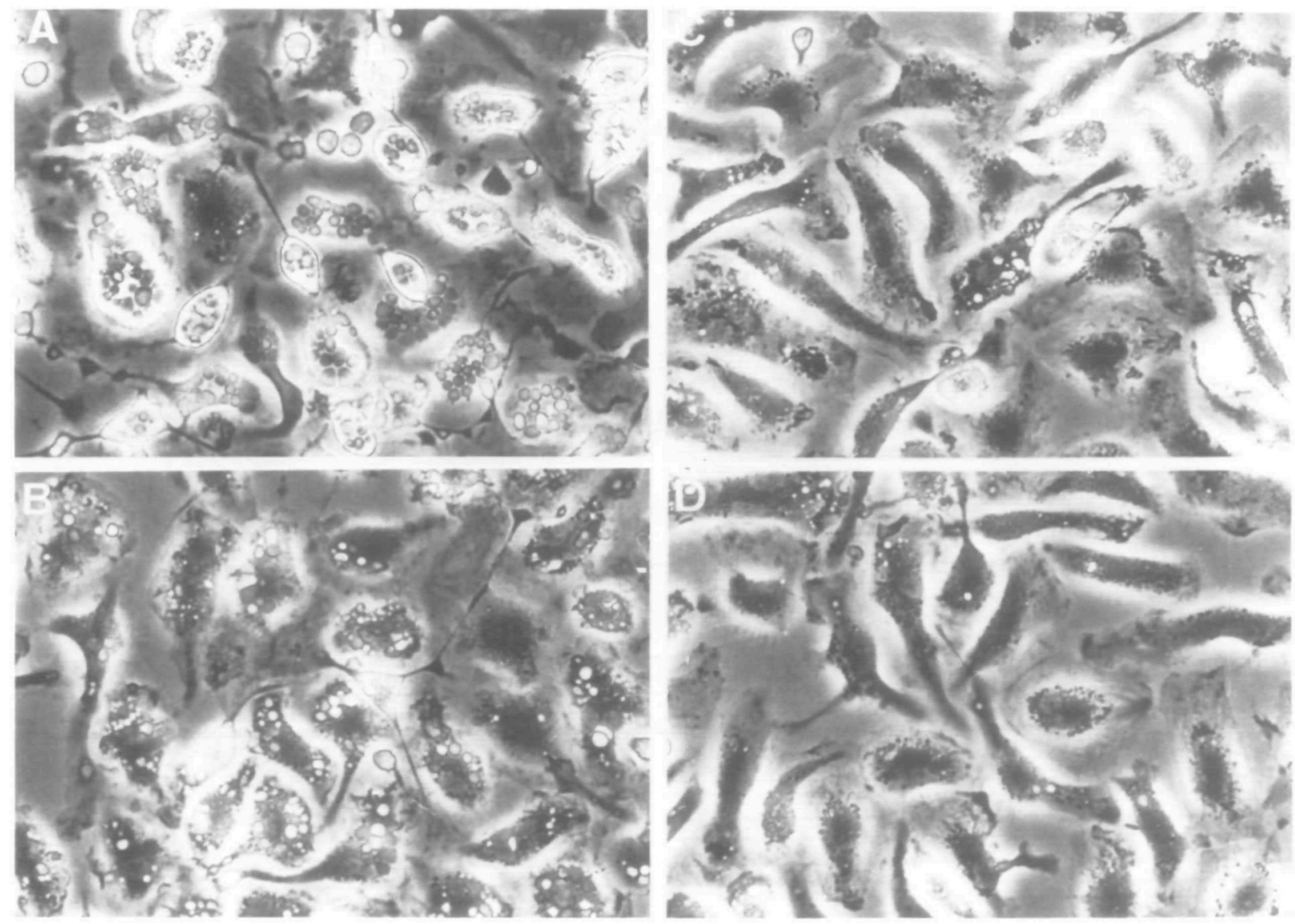

Fig. 4. In vitro phagocytosis by peritoneal macrophages of MRBC opsonized with either $34-3 \mathrm{C}(\mathrm{A}), 105-2 \mathrm{H}(\mathrm{B}), 31-9 \mathrm{D}(\mathrm{C})$, or $4 \mathrm{C} 8$ (D) anti-MRBC $\mathrm{mAb}$. Note the marked and moderate phagocytosis of MRBC opsonized with $34-3 \mathrm{C}$ and $105-2 \mathrm{H}$ mAb, respectively, but the absence of significant phagocytosis of MRBC opsonized with either 31-9D or $4 \mathrm{C} 8 \mathrm{mAb}$. No phagocytosis was observed with MRBC coated with 1E10 anti-MRBC mAb (not shown) 
1140 Monoclonal anti-erythrocyte autoantibodies

Table 5. Effect of anti-Fc $\gamma$ receptor $m A b$ (2.4G2) on the development of anti-MRBC mAb-induced anemia

\begin{tabular}{llll}
\hline mAb & Day 0 & Day 3 & \\
\cline { 2 - 4 } & & $2.4 \mathrm{G} 2^{\mathrm{a}}$ & Control \\
\hline $34-3 \mathrm{C}$ & $47 \pm 1^{\mathrm{b}}$ & $46 \pm 1^{\mathrm{b}}$ & $21 \pm 3^{\mathrm{b}}$ \\
$31-9 \mathrm{D}$ & $49 \pm 1$ & $24 \pm 3$ & $26 \pm 2$ \\
$4 \mathrm{C} 8$ & $49 \pm 1$ & $32 \pm 3$ & $35 \pm 1$ \\
\hline
\end{tabular}

a $1 \mathrm{mg}$ of anti- $\mathrm{F}_{\gamma}$ receptor $\mathrm{mAb}$ (2.4G2) was given i.v. $2 \mathrm{~h}$ before the injection of anti-MRBC mAb.

bHt values (mean of 5 mice $\pm 1 \mathrm{SD}$ ) were determined 3 days after i.p. injection of $100 \mu \mathrm{g}$ of anti-MRBC mAb.

only two (1E10 and $4 \mathrm{C} 8$ ) are able to induce anemia. The marked in vitro and in vivo hemagglutination by pathogenic $1 \mathrm{E} 10$ and $4 \mathrm{C} 8 \mathrm{mAb}$ but not by non-pathogenic 103-7E and 106-10E mAb can be explained by the difference in specificity of these two groups of $\mathrm{mAb}$. It may be that the density of antigenic determinant recognized by $1 \mathrm{E} 10$ and $4 \mathrm{C} 8 \mathrm{mAb}$ is much higher than that recognized by $103-7 \mathrm{E}$ and $106-10 \mathrm{E}$ mAb. Alternatively, the antigen recognized by $1 \mathrm{E} 10$ and $4 \mathrm{C} 8 \mathrm{mAb}$ may be distributed in small clusters on $M R B C$, as recently demonstrated for the complement receptor type 1 on human RBC (19). Such differences in the distribution of target antigens could also account for the difference in in vivo binding to MRBC by these two groups of anti-MRBC mAb.

The present finding that none of the anti-MRBC $M A b$, even $\operatorname{lgM~mAb}$, are able to lyse MRBC in vitro in the presence of complement from mice, rabbits or guinea pigs may not be totally surprising. In fact, non-complement-fixing IgM antibodies with diverse specificities have been described in various species, including mouse $(20-23)$. Since the structure of the antigen appears to influence the capacity of $\lg M$ antibodies to fix and/or activate complement $(24,25)$, the failure of hemolysis by our autoantibodies may be related to the particular structure of the target RBC antigen. This notion was further supported by a recent observation that some lymphocyte surface antigens are better targets for complement-mediated lysis than others, independent of their densities (26). Thus, it may be possible that the antigens involved in anti-MRBC autoimmune responses and bound by anti-MRBC mAb could not efficiently activate $C 1$, probably because of their low mobility in the RBC membrane. Whatever the reason, the development of anemia in C5-deficient DBA/2 mice as well as normal BALB/c mice clearly indicates a minor role, if any, of complement-mediated hemolysis in the pathogenesis of anemia induced by our anti-MRBC $\mathrm{mAb}$. In this regard, it should be noted that NZB mice are congenitally deficient in hemolytic complement activity (27) yet develop severe autoimmune hemolytic anemia. Finally, the complete prevention of anemia induced by the IgG2a 34-3C mAb by the injection of anti-F $c \gamma$ receptor $m A b$ and the similar development of anemia in both C3-depleted and control mice argue against the possible involvement of $\mathrm{C} 3$ receptor-mediated erythrophagocytosis in the development of anemia induced by our anti-MRBC mAb. Notably, our results do not exclude the possibility that combinations of antibodies against different epitopes might lead to complement-mediated hemolysis.

Our in vitro and in vivo results combined with histological examinations have clearly shown that two different mechanisms are responsible for the development of anemia induced by our anti-MRBC mAb. In the case of IgG2a 34-3C and IgG1 105-2H anti-MRBC $m A b$, which bind efficiently to $F c$ receptors on macrophages, the major cause of anemia is apparently a rapid Fc receptor-mediated phagocytosis of opsonized MRBC, most remarkably by Kupffer cells. In contrast, with the two IgM (1E10 and $4 \mathrm{C} 8$ ) and $\operatorname{lgG} 131-9 \mathrm{D}$ anti-MRBC mAb which fail to mediate Fc receptor-dependent phagocytosis, anemia is most likely caused by the marked sequestration of agglutinated RBC in spleen and liver. Subsequent liver damage and hemodynamic failure are likely to be additional contributing factors to the animals' death, explaining why this group of $\mathrm{mAb}$ was more toxic than the first group of pathogenic $\mathrm{mAb}$. It should be mentioned that both $31-9 \mathrm{D}$ and $105-2 \mathrm{H} \mathrm{mAb}$ are of the IgG1 class, yet a substantial difference exists in their ability to mediate $\mathrm{Fc}$ receptor-dependent phagocytosis. Since both $\mathrm{mAb}$ recognize different epitopes, limited phagocytosis of MRBC opsonized with the 31-9D mAb may be due to the difference in the distribution and nature of antigenic determinants recognized by each mAb.

Although the specificity of autoantibodies is important, it is apparent that other factors may determine the pathogenic activity of anti-MRBC $\mathrm{mAb}$. The best example is the difference in the pathogenic potential between IgG2a $34-3 \mathrm{C}$ and $\lg \mathrm{G} 1 \mathrm{105}-2 \mathrm{H}$ $\mathrm{mAb}$. Although both mAb appear to recognize the same epitope, the competition experiment strongly suggested that the affinity of $34-3 \mathrm{C} \mathrm{mAb}$ to MRBC is far higher than that of $105-2 \mathrm{H} \mathrm{mAb}$. In addition, in vitro experiments on Fc receptor-mediated phagocytosis have shown that IgG2a 34-3C mAb exhibits greater binding to $F_{C}$ receptor than does IgG1 $105-2 \mathrm{H}$ mAb, owing to the difference in the affinity of the $\mathrm{Fc}$ receptor for $\operatorname{lgG} 2 \mathrm{a}$ and of the $F_{c}$ receptor for $\lg 11 / \lg G 2 b(28,29)$. Both differences in the affinities of $\mathrm{mAb}$ for the target antigen and for the $\mathrm{Fc}_{\mathrm{c}}$ receptor may well explain the fact that the pathogenic activity of IgG2a $34-3 \mathrm{C} \mathrm{mAb}$ is $~-10$ times stronger than that of IgG1 $105-2 \mathrm{H} \mathrm{mAb}$.

Our present studies have demonstrated several important points: (i) not all the autoantibodies reactive with intact MRBC in vitro are able to induce anemia; (ii) all five pathogenic autoantibodies recognize antigenic determinants expressed only on MRBC but not on other species of RBC, suggesting the importance of the specificity of anti-MRBC autoantibodies; and (iii) the affinities of autoantibodies for the target antigens and for the $\mathrm{FC}_{\gamma}$ receptors of macrophages, and the ability to cause hemagglutination are additional factors determining the pathogenic activity of anti-MRBC autoantibodies. Although it is obvious that the anti-MRBC mAb studied here may not represent the full range of pathogenic anti-MRBC autoantibodies occurring in the NZB mouse, the substantial variation of pathogenic activities observed among anti-MRBC mAb could explain the remarkable individual variability in the progression of autoimmune hemolytic anemia in the NZB mouse. Since recent structural analysis of autoantibodies has revealed the oligoclonal origin of autoimmune responses (30), the selection of different autoreactive clones during the early course of autoimmune responses may markedly influence the onset and progression of autoimmune hemolytic anemia in the NZB mouse. Finally, the development of the experimental model of autoimmune hemolytic anemia described here certainly represents a good opportunity to evaluate various therapeutic approaches based on interference at the level of the essential pathogenic pathways. 


\section{Acknowledgements}

We thank Dr Alex Lussow for critically reviewing the manuscript, Ms Geneviève Leyvraz for histological preparations, and Ms Claire Desjeux for the preparation of this manuscript. This work was supported by grant no. 31-28782.90 from the Swiss National Foundation for Scientific Research, by a grant from the Ministry of Education, Science and Culture, Japan, by the Swiss Confederation acting on the proposal of the 'Commissions Fédérales des Maladies Rhumatismales', and by the Roche Research Foundation.

\section{Abbreviations}

CVF

DMEM

cobra venom factor

ELISA

Dulbecco's modified Eagle's medium

HE

Hit

$\mathrm{mAb}$

MRBC hematoxylin and eosin

hematocrit

monoclonal antibody

RIA

mouse red blood cells

radioimmunoasay

\section{References}

1 Helyer, B. J. and Howie, J. B. 1963. Spontaneous auto-immune disease in NZB/BI mice. Br. J. Haematol. 9:119.

2 Linder, E. and Edgington, T. S. 1972. Antigen specificity of antierythrocyte autoantibody responses to NZB mice: identification and partial characterization of two erythrocyte surface autoantigens. $J$. Immunol. 108:1615.

3 Deheer, D. H., Linder E. J., and Edgington, T. S. 1978. Delineation of spontaneous erythrocyte autoantibody responses of NZB and other strains of mice. J. Immunol. 120:825

4 Miescher P. A. and Dayer, J. M. 1976. Autoimmune hemolytic anemia. In Miescher, P. A. and Müller-Eberhard, H. J., eds, Textbook of Immunopathology, p. 649. Grune \& Stratton, New York.

5 Lewis, D. E., Griswold, S., and Warner, N. L. 1981. Monoclonal anti-erythrocyte auto-antibodies from unimmunized NZB mice. Hybridoma 1:71.

6 Cooke, L. A., Staines, N. A., Morgan, A., Moorhouse, C., and Harris, G. 1982. Haemolytic disease in mice induced by transplantation of hybridoma cells secreting monoclonal anti-erythrocyte autoantibodies. Immunology 47:569

7 Ozaki, S., Nagasawa, R., Sato, H., and Shirai, T. 1984. Hybridoma autoantibodies to erythrocytes from NZB mice and the induction of hemolytic anemia. Immunol. Lett. 8:115.

8 Caulfield, M. J., Stanko, D., and Calkins, C. 1989. Characterization of the spontaneous autoimmune (anti-erythrocyte) response in NZB mice using a pathogenic monoclonal autoantibody and its antiidiotype. Immunology 66:233

9 Cerottini, J. C., Engers, H. D., MacDonald, H. R., and Brunner, K. T. 1974. Generation of cytotoxic T lymphocytes in vitro. I. Response of normal and immune spleen cells in mixed leukocyte cultures. J. Exp. Med. 140:703.

10 Luzuy, S., Merino, J., Engers, H., Izui, S., and Lambert, P. H. 1986. Autoimmunity after induction of neonatal tolerance to alloantigens: role of $\mathrm{B}$ cell chimerism and $\mathrm{F}_{1}$ donor $\mathrm{B}$ cell activation. J. Immunol. 136:4420.

11 Poncet, P., Kocher, H. P., Pages, J., Jaton, J. C., and Bussard, A. E. 1985. Monoclonal autoantibodies against mouse red blood cells: a family of structurally restricted molecules. Mol. Immunol. 22:541.

12 Spertini, F., Coulie, P. G., Van Snick, J., Davidson, E., Lambert, P. H., and Izui, S. 1989. Inhibition of cryoprecipitation of murine IgG3 anti-dinitrophenyl (DNP) monoclonal antibodies by anionic DNP - amino acid conjugates. Eur. J. Immunol. 19:273.

13 Unkeless, J. C. 1979. Characterization of a monoclonal antibody directed against mouse macrophages and lymphocyte $\mathrm{Fc}$ receptors. J. Exp. Med. 150:580.

14 Garcia-Gonzalez, M., Bettinger, S., Ott, S., Olivier, P., Kadouche, J., and Pouletty, P. 1988. Purification of murine lgG3 and IgM monoclonal antibodies by euglobulin precipitation. J. Immunol. Methods 111:17.

15 McConahey, P. J. and Dixon, F. J. 1980. Radioiodination of proteins by the use of the chloramine-T method. Methods Enzymol. 70:210.

16 Bazin, H., Cormont, F., and de Clercq, L. 1986. Purification of rat monoclonal antibodies. Methods Enzymol. 121:638.

17 Cinader, B., Dubiski, S., and Wardlaw, A. C. 1964. Distribution, inheritance, and properties of an antigen, MuB1, and its relation to hemolytic complement. J. Exp. Med. 120:897.

18 Long, G., Holmes, M. C., and Burnet, F. M. 1963. Autoantibodies produced against mouse erythrocytes in NZB mice. Aust. J. Exp. Biol. Med. Sci. 41:315.

19 Paccaud, J. P., Carpentier, J. L., and Schifferli, J. A. 1988. Direct evidence for the clustered nature of complement receptors type 1 on the erythrocyte membrane. J. Immunol. 141:3889.

20 Plotz, P. H., Colten, H., and Talal, N. 1968. Mouse macroglobulin antibody to sheep erythrocytes: a non-complement-fixing type. $J$. immunol. 100:752.

21 Spiegelberg, H. 1974. Biological activities of immunoglobulins of different classes and subclasses. Adv. Immunol. 19:259.

22 Van Snick, J. L. and Masson, P. 1978. The effects of complement on the ingestion of soluble antigen - antibody complexes and $\lg M$ aggregates by mouse peritoneal macrophages. J. Exp. Med. 148:903.

23 Klaus, G. G. B. Pepys, M. B. Kitajima, K. and Askonas, B. A. 1979. Activation of mouse complement by different classes of mouse antibody. Immunology 38:687.

24 Ishizaka, T., Tada, T., and Ishizaka, K. 1968. Fixation of complement and $C^{\prime} 1$ a by rabbit $\lg G$ and $\lg M$ antibodies with particulate and soluble antigens. J. Immunol. 100:1148.

25 Cunniff, R. V. and Stollar, B. D. 1968. Properties of $19 S$ antibodies in complement fixation. I. Temperature dependence and role of antigen structure. J. Immunol. 100:7.

26 Bindon, C. I., Hale, G., and Waldmann, H. 1988. Importance of antigen specificity for complement-mediated lysis by monoclonal antibodies. Eur. J. Immunol. 18:1507.

27 Andrews, B. S. and Theofilopoulos, A. N. 1978. A microassay for the determination of hemolytic complement activity in mouse serum. $J$. Immunol. Methods 22:273.

28 Unkeless, J. C., Scigliano, E., and Freedman, V. H. 1988. Structure and function of human and murine receptors for IgG. Annu. Rev. Immunol. 6:251.

29 Yamada, A and Suzuki, T. 1989. Fc $\gamma 2 \mathrm{~b}$ receptor-mediated phagocytosis by a murine macrophage-like cell line $\left(\mathrm{P}_{\left.388 \mathrm{D}_{1}\right)}\right)$ and peritoneal resident macrophages. J. Immunol. 142:2457.

30 Shlomchik, M. J., Marshak-Rothstein, A., Wolfowicz, C. B., Rothstein, T. L., and Weigert, M. G. 1987. The role of clonal selection and somatic mutation in autoimmunity. Nature 328:805. 